\title{
A Market Friendly Approach to the Construction of a Northeast Asian Economic Hub
}

\author{
Young-Rok Cheong*
}

\begin{abstract}
Arrangements for regional economic integration, under the WTO system, have unexpectedly dominated globalization. In fact, countries that have realized economic arrangements, such as the EU's monetary union, are further expanding their efforts to achieve political integration. Regional economic integration is now considered an exigency of national affairs. North East Asian countries are also affected by this global predicament, but the issue involves greater structural complexities in this region. The emergence of China has forced Japan and Korea to contemplate difficult structural adjustments. For example, while the Korean government recognizes the importance of stronger intra-regional economic cooperation, by pursuing these arrangements it simultaneously faces the dilemma of maintaining traditional partnerships, such as those with the USA and Japan. If Korea actively supports regional economic arrangements, this action would be perceived as a bias toward China, consequently damaging ties with the US. Thus, rather than depending on public initiatives to establish economic ties in North East Asia, China, Japan and Korea should rely on market friendly projects initiated by the private sector that endorse gradual integration through non-political activities and exchanges among the citizens of the respective countries. This paper first proposes the founding of a North East Asian United University Community composed of students, professors and campuses of the three countries in the initial stages. Secondly, it proposes the development of unique Asian commodities, a concept similar to that of 'Airbus.' Finally, it proposes utilization of retired Japanese, Korean and Chinese engineers and technicians to speed up the overall level of technology, which is critical to overcoming backwardness in this region.
\end{abstract}

\section{I. 서 론 ${ }^{11}$}

2003년 시작된 노무현 대통령의 참여정부는 “동북아경제중심"론을 주창하고 있다. 한 때 "동북아경제 중심국가" 개념을 주창한바 있었으나 나중에 "동북아경제중심"으로 재조정한 바 있다고 한다. 이러한 움 직임의 배경에는 더 이상 우리나라가 혼자로만 독자적으로 생존하기가 어렵다는 판단을 내리고 나서, 앞으 로 여하히 세계경쟁 속에서 생존해야 하느냐의 진로를 모색한 결과 나온 하나의 정책방향이라고 해도 좋 을 듯 하다.

* Professor, Graduate School of International Studies, Seoul National University, Seoul, Korea.

" 본 논문은 개략적인 형태로 산업자원부등 정부의 정책참고자료로 제시되었던 필자의 생각을 좀더 학술적으로 발 전시킨 형태이다. 따라서 이것은 학술적인 내용보다는 전반적인 입장의 정립을 주창하는 정책 방향을 좀더 강조하고 있 는점이 특징이다.

๖ “동북아경제중심국가”란 용어에 대해서 중국측이 그 뜻이 무엇인지를 해명하기를 요청했고, 이에 대해 우리측이 “동북아경제중심"으로 축소했다는 설이 있다.

3) 국정과제 참조 Website 
한국은 현재 IMF관리하의 경제위기를 거치면서 전반적인 경제구조 조정을 단행하고 있는 실정이다. 즉 우리는 21 세기 진입이래 국가발전, 특히 개인소득 1 만달러를 넘어서고 난 후의 선진국 정착을 위한 다양 한 방안을 모색하고 있다. 이를 위해서 새로운 국가정책으로서의 비젼제시가 요구되고 있기조차도 하다.

그런데 “동북아경제중심론”은 새로운 움직임은 전혀 아니다. 이는 이미 1985 년의 PLAZA합의를 깃점 으로 한 1980 년대 중반 이후 한 때 국내에서 거론되었던 주장"의 연장선상에 있다. 1980 년대 중반이후 국내 에서는 동북아경제공동체 구상에 대한 논의가 학계 및 언론계를 중심으로 적극적으로 제기된 바 있었다. 특히 이는 1990년대 초의 노태우 대통령 재임 당시에 북방정책의 추진과 “동북아경제공동체"설립의 구상 으로 상당히 구체적으로 논의된바 있었다. WTO체제가 출범되고 나서 요즈음 또다시 세계가 냉전체제의 와해이후 한편으로는 세계화로 옮아가고 있는 가운데에, 또 한 편으로는 아이러니컬하게도 다시 국가간의 짝짓기에 나서게 됨에 따라서 우리나라도 새로운 진로모색이 불가피해 진 것이다. 대외의존돈 가 $70 \%$ 를 넘어서는 우리로서는 고차원의 방정식을 풀어야 하는 다양한 고려 속에서 진로를 선택해야 하게 되었다. 일부 정치학자들은 이를 $19 \mathrm{C}$ 말엽 한 - 중 - 일의 관계가 무척 복잡하게 얽혀 들어가고 있을 구한말 당시로 비유하는 경향도 있다. 특히, 당시 일본주재 중국외교가이던 황준시엔(황준헌) ${ }^{6}$ 이 쓴 조선책략을 재음미 하는 시도도 있는 실정이다. 물론 시대의 변화를 감안한다면 그 비유가 꼭 타당한 것만은 아니다. 그러나 전체적인 맥락에서는 몇 가지 의의를 도출하기는 충분한 것 같다.

이처럼 국가간 경제협력이 다양한 측면에서 논의되고 있는 것은 일단은 다음과 같은 요인으로 설명될 수 있을 것이다. 즉 세계화의 진전, 지역주의의 강화, 세계적인 산업 구조조정압력, 중국의 부상에 따른 우 리나라 활로 개척등으로 요약 될 수 있다. 따라서 본 논문은 기본적으로 동북아경제중심론 추진의 타당성 을 고찰하되 구태여 정부가 주창하기 이전에 이미 시장친화론적인 역내의 경제긴밀화가 일어나고 있다는 전제하에서 논리를 전개하고자 한다. 즉, 입지론적인 관점에서 과연 우리가 지닌 비교우위가 어디에 있으 며, 이러한 평가하에 보다 현실적인 입장정립이 필요하다는 것을 주창하고자 한다. 따라서 본고는 세계화 속의 지역주의 진전배경 등을 좀더 상술하고 나서 입지론적인 관점에서 한국의 비교우위를 평가해보고 역 내 경제협력 강화에 대한 방향등을 전반적으로 다루고자 한다.

\section{II. 지역주의 추세의 필연성}

\section{1. 배 경}

(1) 세계화의 진전

1945년 8월 2차 세계대전이 종결되고 난 후 무려 반세기를 지속하던 냉전체제가 1991 년 구소련의 극적 인 해체에 따라서 세계는 급격한 변화를 격고 있다. 이제 세계는 보기에 따라서는 아시아가 영국의 중국과 의 아편전쟁의 시발로 시작된 19 C중엽이후의 커다란 국제화의 흐름을 반복하고자 하는 듯 보이고 있다.

* 사실 그 당시는 일본이 미국으로 부터의 압력으로 엔화의 고평가로 갈 수 밖에 없게되고 그러한 맥락에서 "환일본 해경제권 주장"이 제기되었으며 이것이 다시 다소 변형된 형태로 우리나라에서 논의 되기 시작한 것으로 판단되고 있다.

s) 대외 의존도는 다양한 지표가 있으나 여기서는 통상적으로 받아들여지는 바처럼 수출과 수입이 전체 GDP에서 차지하는 비중으로 계산하였다.

- 청말의 외교관으로서 광동성 출신이다. 초대 주일공사 허루장을 따라 일본에 가서 청나라 참사관으로 활약했다. 조선의 수신사 김홍집과의 만남에서 "개인적인 의견으로서의 조선책략”인 “親中國結日本 聯美國”을 주장하였다.

" 대표적인 학자가 서울대학교 하영선 교수로 그는"신조선책략론"을 주장하고 있다. 즉 중국과 의존관계를 강화 하면서 미국을 끌어들여 러시아와 일본의 영향력을 차단하였던 시도로 이해한다. 따라서 현재는 미국과의 관계도 지속 하면서 중국과의 관계를 회복시키는 소위 “불륜의 관계"를 지속해야 한다는 우리나라 선택의 복잡성을 주장하고 있다. 
세계의 정치, 경제 질서 측면에서는 현재의 상황은 미국의 강력한 힘을 바탕으로 해서 이미 정치적으 로 UN, 경제적으로 WTO라는 두 축을 중심으로 해서 큰 질서를 잡아가고 있다. 물론 미국이 때로는 UN 이나 WTO의 결의를 무시하는 듯한 움직임이 간헐적으로 나오게 됨에 따라서 UN이나 WTO의 유효성에 일부 의문을 제시하고 있는것도 사실이다.

그러나 한 때 서방과 공산진영으로 나뉘었던 두 무대가 하나로 통합된 것은 엄청난 변화를 몰고온 것 이 사실이다. 그러면 우리는 이처럽 경제활동 무대가 단일화 된 것을 환영하며 이로부터 이익을 얻고 있는 가? 우선 우리나라는 과거 냉전체제하에서는 서방진영에서만 제한적으로 경쟁해야 했었는데 세계화가 진 전됨에 따라서 러시아, 중국, 동구선진국가들이 우리의 경쟁상대로 등장하게 되었다. 그 만큼 시장도 커졌 지만 경쟁상대가 늘어나게 되었다.

일부에서는 최근 우리나라가 겪고 있는 급격한 경제구조 조정을 세계화에서 기인된 것으로 보며 우리 의 과거 발전이 냉전의 반사이익 이었다고 다소 깎아내리는 듯한 자조섞인 평가를 내리기조차 하고 있다. 즉 과거 우리의 경제 발전이란 것이 소위 내재적인 힘의 축적에 의해서 전적으로 유발된 것이 아니라 상당 부분 친서방, 친미편에 서게 됨으로써 경제발전이 촉발되었다는 주장을 하고 있다. 즉 1960 년대의 미국의 원조혜택, 그 이후의 미국시장의 확보(1960 현재), 월남시장의 진출(1960년대 후반 1970년대 초반), 중동 시장의 향유(1970년대 중반 1980년대 중반)등이 가능하였으며 이에 따라서 경제가 비교적 순조롭게 보호 막 속에서 성장하게 되었다는 논지이다. 물론 이것은 상당한 정도의 설득력을 갖고 있는 측면이 있다. 그 러나 이러한 현상이 우리경제 발전의 모든 것을 대변해 준다고 한다면 우리의 내부적인 노력이 너무 무시 되는 참담함이 있다.

어쨌든 우리나라는 세계화의 진전에 따라서 새로운 적응을 모색해야 한다. 어쩌면 그 이전의 시대보다 더 어려움을 맞이하게 된 것으로 볼 수도 있다. 또한 때로는 독자적인 노선을 걸어야 하는 새로운 부담을 안게 된 것도 사실이다. 과거의 동방과 서방으로 분리된 체제하에서 상상하지 못했던 중국, 러시아 등이 이제 우리의 경제적 경쟁자로 엄연히 대두되고 있는 것이 사실"이다. 이러한 현상은 일면으로는 Paul Kennedy등 많은 역사학자들이 거론하는 바처럽 "역사적 윤회"현상"으로 치부할 수 도 있다. 이렇게 되 는 경우 우리나라는 19 C당시 적어도 국가간의 관계에 있어서는 과거 역사시대로 회귀하고 있다고 판단할 수 도 있다. 이러한 측면에서 동북아 역내 국가간의 관계강화에 대한 중요성이 대두되고 있는 것으로 평가 할 수 있다.

(2) 지역주의의 강화

둘째로 세계는 역시 이웃과 반목하면서도 가장 긴밀하게 더불어 살게 되며, 그만큼 이웃나라와의 관계 가 강조되는 지역주의가 편한 측면도 있다. 국제경제학에서도 중력이론(gravity model )이 전통적으로 그 중요성을 얻게 된 것도 이러한 연유"에서 일 것이다. 사람이란 기본적으로 보수적인 존재인지도 모른 다. 그리고 인간은 일평생 새로이 인식하는 범위란 것도 극히 제한적 일 수 밖에 없다. 또한 아무리 사고 를 넓게 가진다해도 공간 개념은 아직은 국내에서, 인근국가로 또는 우리가 속한 대륙에 한정하게 되는 한 계가 있는 듯 하다.

${ }^{8}$ 이와 관련 미국 내에서는 미국의 역할을 로마제국에 비유하는 움직임을 보이고 있기 조차하다.

" 재미난 것은 중국은 그래도 GDP에 의하면 그 경제규모가 1 조 2 천억 달러나 되어 현재도 그 강대국의 지위를 유 지하고 있으나, 러시아는 $\mathrm{GDP}$ 규모가 3,600 억 달러정도로 우리나라에도 못 미치고 있는 실정이다.

100 Paul Kennedy(1989) 참고.

it) 이는 뉴톤의 물리학이론을 사회과학에 응용한 것으로 사람, 정보, 물품의 이동이 인구의 크기, 두지역의 거리에 의해 결정된다는 것이다. 
이것이 세계화속에서 지역주의가 대두되는 모순의 한 측면 일 수도 있다. EU가 근 반세기의 갈등과 협상 속에서 역내 협력을 강하게 달성하는가 하면, NAFTA도 미국의 주도에 의해서 그 경제적 지위를 키 움은 물론이고, 역내 지역간 교류가 활성화 됨으로써 상당한 정도의 경제적인 효과를 나타내고 있다. 이미 $\mathrm{EU}$ 는 통화통합단계 ${ }^{22}$ 를 뛰어넘어서 정치적인 통합으로까지 거의 진전되고 있다. NAFTA는 그 출발은 역내 관세율을 내리는 자유 무역지대의 개념이었으나, 이제는 요소(특히 인력중심)의 이동도 아주 적극적 으로 일어나고 있는 실정이라고 할 수 있다.

(3) 세계적 산업구조 조정

세계경제는 현재 대단위의 산업 구조조정에 직면하고 있다. 이는 기본적으로 생산력 측면에서, 냉전의 와해이후 급격한 IT 혁신브응에 의해서 수요에 비해 생산력이 월등히 향상되었다는 것을 반영하고 있다. 즉, 생산시장 포화상태가 심각하게 나타나고 있다. 과거 우리의 경제발전의 꿈이란 최근의 중국의 발전전 략 ${ }^{10}$ 에서 극명하게 나타나고 있듯이 “절대빈곤의 극복" $\rightarrow$ "최저문화 생활의 달성” $\rightarrow$ 그리고 "복지사회의 실현”등을 단계적으로 추구하는 다소 소박한 것이었다고 할 수 있을 것이다. 현실생활의 보다 구체적인 측 면에서는 1 단계는 단순히 식량증산 등에 그 1 차적인 정책 목표가 맞추어지면 될 것이고, 2 단계는 보편화된 가전제품의 보급, 3 단계는 여가생활의 향유 등으로 간단하게 상정할 수 있을 것이다. 그러나 현재 세계은 행의 “세계발전보고 (World Development Report)"가 집계하고 있듯이 전 세계인구의 $3 / 4$ 이상이 이미 1 단계를 극복하고 있다고 볼 수 있다.

따라서 이러한 상태라고 한다면 산업혁명이 추구하던 대량생산에 의한 대중 소비단계는 200여년이 지 난 현재 상당한 정도 달성되었다고 평가 할 수 있다. 그 만큼 세계시장이 포화된 상태이고, 신규시장이 줄 어들고 있다고 평가할 수 있을 것이다. 이를 생산측면에서 재평가해 본다면, 설비의 과잉이라고 단적으로 말 할 수 있다. 이 과잉 설비를 여하히 처리해야 하느냐 하면 국내시장에서 해외로 진출하여 투자에 나서 거나, 아니면 국내에서 조업을 폐기하는 방법밖에 없게 되는데 이러한 조정과정에서 결국 국가간에 대대적 인 산업구조 조정을 할 수 밖에 없게 되며, 이러한 측면에서도 역내 경제통합을 가속화 시킬 수 있는 여지 가 있는 것이다. 1990 년대 중반이후 전 세계 FDI가 연간 1조 달러를 한 때 넘어섰다든지, M\&A가 선진국 사이나, 또는 선진국과 후진국 사이에 대대적으로 이루어지고 있는 현상도 이와 전혀 무관치 않다 ${ }^{15}$ 고 할 수있다.

(4) 중국경제의 호조에 따른 우리나라 할로의 개척

이러한 몇 개의 세계 및 지역적인 현상에다 더해서 우리나라는 바로 인근 국가인 중국의 경제적 부상 에 따라서 여러 가지 복합적인 문제에 직면하게 되었다. 최근 국내에서는 중국의 경제적 부상에 따라서 “중국위협론”과 “중국기회론”, 또는 “중국절대부강론”등이 교챃ㅎ하고 있다.

12 경제 통합론의 시조인 Bella Ballasa는 경제통합의 단계를 자유무역지대, 관세동맹, 공동시장, 통화동맹, 정치동 맹 단계로 각각 나누고 있다.

17 $20 \mathrm{C}$ 후반부터 $21 \mathrm{C}$ 초반의 각종 혁신은 기본적으로 냉전체제의 와해에 기인된 측면이 강하다.

10 덩샤오평 선생은 이를 溫包 $\rightarrow$ 小康 $\rightarrow$ 大同으로 이전하게 된다고 주장하였다.

15. 사실 외국인 투자의 유치는 많은 논란을 불러 일으킨 바 있으며 제국주의 시대에서는 극도로 기피된 바 있다. 이 후에도 상당기간 선진국의 전유물로 치부 된 바 있다. 그러나 1980 년대 중반이후에는 해외투자가 보다 보편화 되고있는 것으로 평가할 수 있다. 이러한 현상을 반영하여UNCTAD는 추가된 FDI의 중요성을 감안해서 매년 통계치를 집계, 출 판하고 있다.

16) 이는 국내는 물론이고 해외에서도 성행하는 것으로서 중국이 세계를 위협하고 있다는 측면과, 중국의 고도성장 을 통해서 세계경제가 공동발전 할 수 있다는 낙관적인 견해로 나뉘고 있다. 한편, 일부에서는 중국이 내재적인 힘에 의 해서 자생적인 발전을 할 수 밖에 없다는 절대 부강의 잠재력이 있다는 견해도 보이고 있다. 
업계에서는 “부메랑”, “산업공동화우려론”이 대두 된지 오래다. 필자는 최근 연구"를 통해서 우리나 라 절대투자가 오히려 줄어들고 있는데 반해 중국내의 투자는 연율 $15 \%$ 이상으로 증가되고 있다는 것을 중 시, 우리의 성장 잠재력이 중국에 비해 크게 줄어들고 있는데 대해 우려를 표시 한 바 있다.

이러한 맥락에서 하나의 대안으로써 중국과의 경제적 긴밀화를 추구하는 것을 포함한 동북아경제협력 의 강화가 검토되고 있는 것으로 판단되고 있다.그러나 과연 역사적으로 보아 중국과 어느정도 관계를 밀 접하게 하고 선을 그어야 할지는 가치판단의 문제로 그리 간단하지 않을 것이다. 우리나라는 대외의존도 가 $70 \%$ 이상으로 세계 250 여개 국가 가운데서도 홍콩, 싱가폴등과 함께 극도로 대외의존적이며 그 측면에 서 단지 중국과의 경제 긴밀화만을 일방적으로 추구할 수 는 없는 어려움이 있다. 즉 일방적으로 중국과의 관계만을 강화하는 경우 여타 국가들과의 관계 원활화에 있어서 장애가 될 수도 있다. 따라서 대중관계를 포함해서, 대일본관계 등을 전체적으로 재점검해 볼 필요가 있을 뿐아니라 역내 경제협력강화 차원에서 “동북아경제중심"을 추구할 개연성은 충분히 있다. 다만, 과연 “동북아경제중심”의 비젼이 무엇이며 어떤 것을 목표로 추구해야 하는지가 아주 중요하다고 본다.

\section{2. 기존 역내 경제협력 모델평가}

WTO가 집계한 지역협력의 사례는 근 200 여개에 달하고 있다고 한다. 그러나 우리의 인식 범위에서 비교적 성공하고 있는 사례로서의 역내경제협력의 것으로는 몇 개 되지 않는 듯 하다. 또한 우리와 연관된 실패의 사례도 몇 개가 있다. 즉 성공, 실패의 예가 절대적으로 많다고 평가 할 수 없다.

아무래도 역내 경제헙력의 성공모델은 유럽형과 미국형을 거론 할 수 있을 것 같다. 한편, 우리나라와 또는 아시아와 연관지어서 거론될 수 있는 것은 일본이 1930년대에 주창한 "대동아공영권"형성 움직임라과 1985 년 이후 한 때, 추진한 바 있는 일본의 동남아에서의 "Yen Bloc"형성 움직임"이랄 수 있다. 필자는 경제 통합 움직임의 성공 - 실패 요인으로 정치 - 경제적요소를 거론한 바 있다. 즉 한 개의 역내 경제협 력이 성공하기 위해서는 역내국가 중에서 주도국가가 있어야 되며, 그 역내협력강화의 성패는 주도국가의 정치력에다가, 경제적으로 유관 역내의 경제규모가 자급시장 규모가 되거나 세계경제와 비교해서 일정규 모를 갖추어야 하며, 또한 교역에 있어서도 역내국가간 교류비중이 적어도 $40 \%$ 이상은 되어야 하는 것으로 주장한 바 있었다. 또한 역외와의 교역 또한 특정 지역에 편중되지 말아야 한다는 것이 전제되어야 한다. 이러한 측면에서 EU와 NAFTA는 출범 초기부터 그 성공이 거의 보장 되었다고 해도 과언이 아니다. 즉 $\mathrm{EU}$ 는 독일과 프랑스의 지도력에 의해서 $\mathrm{EU}$ 지역을 통합시킴으로써 역내 회원국간의 경제적 이익이 상당 한 정도 제고되었으며, 역내 경제규모로나, 역내교역 비중으로 보아서 경쟁관계보다는 보완관계가 강하게 나타나고 있었다고 판단되었다. 한편 NAFTA 또한 EU와 거의 유사한 정도의 전제조건이 만족되고 있었 다. 즉 미국의 지도력 하에서 멕시코와 카나다간의 분업구조가 상당한 정도 효율적으로 일어나고 있었다 고할 수 있다.

${ }^{n}$ 동 프로젝트는 한국은행과 공동으로 진행된 것으로서 IMF관리체제 진입이후 최근 5 년간 외환으로 환산한 우리 나라 절대 투자액을 기준으로 해서 평가한 것이다. (졸고 2003b참조)

is 구체적인 것은 손병해(2002)P42-47에 잘 정리되어 있다.

19) 이를 "신아시아 공업개발계획"이라고 한다. (졸고 1996.12참조)

m 졸고(1992)참조. 
(1) 성공 사례

(1) 유럽형(EU)

유럽모델은 사실 그 근원이 1950 년대로 거슬러 올라가며, 기실은 그 근원이 수백년 전으로 까지 거슬러 올라간다는 주장 ${ }^{21}$ 도하고 있는 실정이다. 어쨌든 유럽형의 등장은 10 여개 이상의 많은 국가들이 한 개의 경제 권역을 형성함으로써 민족갈등, 이념갈등 등의 극복이 포함된 안보적인 안정과 경제발전의 달성이라 는 일차적인 목적을 달성할 수 있었다고 할 수 있다. 이러한 상황 하에서는 일종의 게임이론적 관점에서 보더라도 최적의 해는 경제통합을 이룩하는 것이 독자 노선을 가는 것 보다는 낫다는 결론을 얻고 있는 것 이다. 즉 유럽, 특히 서유럽구성 국가들은 1958년 EEC로부터 출발하되 1967년 관세동맹, 1968년 공동농업 정책, 1992 년의 공동시장단계를 거쳐서 2002년의 통화통합에 이어서 이제는 거의 정치적인 조율도 거치는 “유럽공동체사회”로 옮겨가고 있는 과정에서 대승적인 이득이 있다고 평가하고 있는 것이다.

이처럽 유럽형의 경제통합이 성공할 수 있었던 근원에는 역시 프랑스의 Jean Monet와 Schuman이라 는 탁월한 정치지도자가 있었다. 특히 역내국가 간에 국가 경제발전에 절대적 요소이었던 전략 및 안보물 자이던 철강, 석탄을 서로 나누어 사용하는 대승적인 정치 지도력이 발휘된 결론에 도달할 수 있었으며, 역 내 국가간의 경제교류를 적극적으로 강화(긴밀화) 하는 한편, Airbus등 소위 유럽형 산업협력을 구체적이 고도 상징적으로 성공시킨 사례가 그 성공의 바탕이 되었던 것으로 평가된다.

\section{(2) 미국형(NAFTA)}

NAFTA의 전신은 1989년의 미 · 캐나다 자유무역지역 (Canada - US Free Trade Area)협정이었으 며, 이것이 멕시코를 포괄함으로써 1994년에 NAFTA가 정식으로 출발하였다. 이는 미국)캐나다>멕시코 라는 경제적인 규모순위나 발전수준에 있어서 “미국형 기러기모형"의 발현이라고 해도 과언이 아닐 것이 다. 즉 미국의 정치, 경제적인 측면에서 절대적인 지도력 하에서 캐나다. 멕시코가 수직적인 경제통합 - 결 합을 이룩하게 됨으로써 그 성과가 나타나고 있다고 할 수 있다. 즉, 미국을 중심으로 캐나다, 멕시코가 보 조하는 전형적인 주종관계의 경제교류가 역내에서 할성화되는 또하나의 성공모델을 제공하고 있다. 따라 서 유럽형의 성공이 힘의 크기가 엇비슷한 국가간의 경제통합(homogeneous integration)이라고 한다면 미국형은 국가간의 국력차가 현격한 이질적인 국가간의 경제통합(heterogeneous integration)이라고 칭 할 수 있다.

\section{(2) 실패 사례}

\section{(1) 일본형}

아시아에서도 역내 경제통합의 시도는 이미 있었다. 그런데 역내 국가간의 합의를 도출하는데 실패함 으로써 역내 경제협력의 도출은 실패하게 된다. 이는 일본의 경제적 성공이 내재적인 것이었다라기보다는 외재적인 것이었기 때문으로 분석된다. 일본의 경제적인 도약은 우선 세계에 대한 인식을 아시아 국가 가 운데서도 제일먼저 하게 된데 있다. 즉 중국, 한국, 일본 가운데 중국은 1840 년대의 아편전쟁의 패전에도 불구하고 청나라 제국의 진로에 대한 심각한 반성이 20 세기 초 까지 아직 구체적으로 실현된게 없었다. 이 에 반해 일본은 1852 년 흑선의 도래로 커다란 충격을 받은 지식인층에서 일본을 철저하게 개혁해야 세계 국가로 태어날 수 있다는 인식하에 신사유람단을 통해 서구의 변화를 적극 수용한 결과, 아시아에서 선두 주자로 등장하게 되었다고 할 수 있다. 그러나 그것만이 최선은 아니었다.

21) 이는 프랑스의 수상 Schuman에 의해서 유럽철강석탄공동체로 구체화 된다. 하영선교수는 수백년간의 유럽 국 가간의 반목이 역사적으로 구성원들로 하여금 심리적으로 역내 통합의 잇점이 있다는 결론으로 도달하게 되는 배경이 되었다고 주창하고 있다. 
일본은 산업혁명의 발현으로 시장의 범위를 확대해야 만이 생존하게 된다는 강박관념 하에서 1930 년대 한때 "대동아공영권"을 추구하게 되었다. 그러나 이는 일본을 중심으로 한, 앞에서 거론한 “미국형"에 근 접하게 됨으로써 잠재적 협력 상대국으로부터 합의를 얻어내지 못하게 되었으며, 결과적으로는 실패하게 된다.

일본은 20세기 말에 또 한 번 역내 경제협력을 추구하게 된다. 일본은 1985 년을 전후해서도 plaza합의 후 소위 "엔화의 강세"에 대응하기 위해서 ASEAN 국가들과의 경제협력을 강화코자 하는 "신아시아 공 업개발계획"노선을 주창하게 된다. 하지만, 이 또한 과거 유산의 미청산으로 실패하게 된다. 물론 ASEAN에서는 화교 경제권이 강하게 자리잡고 있음으로써 일본의 ASEAN의 역내 경제친화 노력이 여 의치 못했으며, 결과적으로 실패하게 된 배경으로 작용하기도 하였다.

(2) 한국형

우리나라가 구체적으로 양국간 경제협력에 나서게 된 것은, 사실은 역사가 아직 짧다. 1994년 한국과 중국 간에 “한 - 중 산업협력 협정”을 체결했던 것이 그것이다 그 당시 논의되던 “동북아경제공동체구상" 을 보다 실현성 있는 현실 수준으로 끌어내리면서 우리나라가 가장 필요로 하는 산업분야만을 중심으로 한 . 중간에 협력을 끌어내자는 취지에서 시작 되었다고 할 수 있다. 즉, "동북아경제공동체” 구상이 너무 탈 서구적(미국적)이라는 오해를 불식시키기 위한 배경하에서 나타난 바 있었다. 그러나 이 또한 몇 가지 연 유에서 결과적으로는 그 성과가 지지부진하게 되었다.

첫째, 우리나라가 자본, 기술, 인력에서 뚜렷한 우위가 불비한 상태에서 협력협정의 성사에만 매달리는 전시 효과만 겨낭한 문제점이 있었다. 산업협력의 분야를 보면 중형항공기, 전자교환기. HDTV, 그리고 자동차 등으로 그 당시만 해도 첨단산업군에 속하는 산업들인데 냉철하게는 우리나라가 세계적으로 완전 한 우위를 차지하지 못하고 있었다. 그런데도 우리만의 이익에 집착하여 이 분야에서 중국과의 공동노력 이 한국의 입지를 강화 할 수 있다는 확신 하에서 김영삼 대통령 당시의 주중대사였던 황병태 박살의 지 도력에 의해서 추진 된 바 있었다.

둘째, 한국의 기술경쟁력 우위에 대한 과신이었다. 즉 우리의 평균적인 경쟁력은 중국의 평균적인 기 술 수준에 비해 우위에 있었던 것이 사실이었다. 하지만 원천기술이나 기초기술 분야에서 우리나라가 그 렇게 앞서가고 있다고 평가하기 어려운 측면이 있었다. 구체적으로 산업협력의 협의가 이루어지자, 결국 우리업체들이 해외 제휴선을 찾을 수 밖에 없게 되고 이러한 사실을 간파하게 된 중국으로서는 구태여 한 국을 거치지 않아도 그들이 필요한 기술취득이 기술공여 국가들로부터 직접 가능하다는 판단하에서 점차 흥미를 잃게 되었다. 즉 선진국의 수많은 다국적 업체 등이 경쟁적으로 우리나라보다 더 좋은 조건으로 상 기 개별산업에서 중국과의 협력을 원하고 있었으며 중국은 자국발전에 최적인 방법만을 선택하기만 하면 되게 되어 있었다. 물론 그 이후 CDMA에서 협력을 끌어냈다든지 하는 면에서는 부분적인 성공은 있었으 며 이를 과소평가 할 수 만은 없다. 그러나 전반적으로는 성공했다고 평가하는 데는 무리가 있었다.

그러면 우리나라는 여기서 역내경제협력체 구상을 포기해야 하는가? 아직도 최종적인 결정을 내리기 는 어려우며, 다시 한 번 전반적인 검토가 필요하다. 특히 무역과 투자가 나날이 역내로 집중되는 자연발 생적인 시장의 힘이 이미 작용하기 시작한 것으로 판단됨으로써 우리의 입장도 보다 명확히 해야할 필요가 있다. 즉, 구태여 정부가 전면에 나서지 않는다 하더라도 시장의 힘에 의해서 자연발생적으로 역내경제협 력의 긴밀화는 불가피하게 진전될 수 밖에 없다고 본다.

${ }^{m}$ 그는 미국 버클리 대학에서 스칼라피노교수 밑에서 “유학사상”으로 박사학위를 취득한 바 있다. 


\section{III. 역내 경제협력강화 방향}

\section{1. 역내 경제협력 필요성의 일반적 논의}

우리는 1995년 WTO출범 이래의 세계화 시대에서 아시아가 가지고 있는 한계도 극복해야 하면서 아시 아의 경제적인 발전을 추구하기 위해서 장기적으로 독자적인 단위 경제구조를 형성할 필요가 있다. 이것 이 역내뿐 아니라 역외에서의 발전에 대해서도 큰 기여가 될 수 있을 것이다. 앞에서도 지적했던 바처럼 이러한 작업은 10 년이나 20 년 이내에 가시적인 성과를 거두기는 거의 불가능하다. $\mathrm{EU}$ 의 경험에 비추어 본다면 한 세대이상이 걸리기도 한다. 그러나 역내 경제협력은 중 - 장기적으로 자연발생적으로 진전될 것 이며 이러한 측면에서 시장친화적인 방향으로 추구되어야만 할 과제임에 틀림없다.

(1) 아시아적 한계의 극복

역사시대 이래의 전 세계 발전에서 소위 근대랄 수 있는 최근 200년간을 뒤돌아본다면 우리의 아시아 적인 발전은 몇 가지 한계가 있었던 것 같다. 우선, 아시아적인 발전은 내재적인 힘의 축적도 중요하였지 만 더 중요했던 것은 외국(또는 역내)으로부터 지식은 물론이고 부까지도 끌어다 쓴 것이었다. 물론 근대 화 이전의 국가까지 포괄한다면 중국이 한 때 세계국가로서 세계경제 발전의 중심에 섰던 적이 있었다. 그 당시는 중국의 폐쇄주의 시대로서 아시아가 생산과 소비의 중심에 있었으며 이는 현재의 현상과 커다란 차

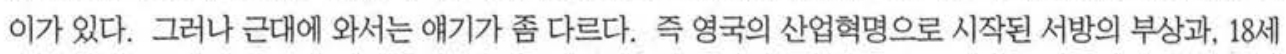
기 무렵의 중상주의적인 흐름이 세계경제계를 횝쓴이후 일본을 제외한 아시아는 쇠락의 길을 걸어가게 되 었다.

또 하나는 아시아가 제 2 차 세계 대전이후 본격적으로 발전하는 과정에서 역내시장 보다는 역외시장에 주로 의존했던 것을 지적할 수 있다. 그 결과 현재로는 한단계 발전하기 위해서는 새로운 Paradigm의 형 성과 역내시장 확대가 급선무라고 할 수 있다. 즉 더 이상 중상주의적 행태리를 지양하는 한편 역내시장 확 대를 위한 구성국가들의 공동노력이 그 어느 때 보다도 요구되고 있는 것이다.

마지막으로 한국, 중국, 일본등 개별적인 국가발전의 개념이 아니라 EU나 NAFTA에 보완되는 아시 아 역내 경제 긴밀화 내지는 통합을 통해서 아시아가 미주대륙, 유럽대륙과 함께 마치 솥의 3 각다리 처럽 세계적으로도 경쟁하면서 협력하게 되는 최적 경쟁지역의 하나의 구성원을 만드는 것이 필요하다고 볼 수 있다.

(2) 시장의 확대

역내 국가의 핵심인 한 · 중 · 일의 경우 2000년 기준으로 수출과 수입을 전체 GDP에서 차지하는 비중 으로 계산해낸 대외의존도의 경우, 한국이 $72 \%$, 중국이 $43.9 \%$, 일본이 $17.9 \%$ 전후로 집계 ${ }^{2 n}$ 되고 있다. 즉 한국이나 중국은 대외 부문이 국내경제 경기에 거의 결정적인 영향을 미치게 된 것으로 추정되고 있다. 물 론 중국은 아직도 완전히 자본주의 국가로 탈바꿈하지 않음으로써 중국의 대외의존도가 표면적으로는 높 게 나타나고는 있으나, 실제로 대외의존도가 그렇게 높지 않을 것으로 추측되고 있다. 그러나 대외의존도 가 높은 만큼 역내경제가 불안정하게 된다면 동아시아 역내지역이 크게영향을 받게 될 것이다.

${ }^{23}$ 최근 Economist지가 거론한 "Oriental Mercantalists "도 이와 전혀 무관치는 않다. (구체적인 것은 The Economist September 20th 2003참조)

${ }^{20} \mathrm{KITA}(2002)$ 참조 
앞에서 거론한 대외의존도는 물론이고 교역에 있어서도 역내의존도를 상당히 제고시킬 필요가 있다. 당장 2000 년을 기준으로 한다면 각 국의 역내의존도는 한국이 $22.6 \%$ 로 가장 높고, 다음이 중국으로 $21.2 \%$, 마지막이 일본으로 $12.7 \%$ 에 불과하다. 따라서 적어도 역내의존도를 두 배 이상은 올려야지 역내 경제통합 의 선두주자인 NAFTA나 EU의 수준 ${ }^{25}$ 에 도달 할 수 있을 것이다.

이러한 점을 감안한다면 동아시아는 보다 안정된 자체발전의 탄력을 받을 수 있도록 해야 할 것이다. 즉 역외의 불안정한 시장보다는 역내의 보다 안정화된 시장을 키우고 발전시켜 나갈 필요가 있는 것이다.

\section{(3) 중국의 고속성장 탄력 활용}

한 - 중 - 일이 포함된 동아시아 시장은 연간 총 6 조 5,000 억 달러 정도로 세계전체 경제규모의 $20 \%$ 를 약간 넘어서고 있다. 그런데 절대규모면에서는 일본 4 조 8,000 억 달러, 중국 1 조 2,000 억 달러, 한국 4,800 억 달러 등으로 일본과 중국의 규모가 우리보다 월등히 크게 나타나고 있다. 우리나라로서는 일본이나 중국 의 경제발전이 우리의 성장이나 발전에 좋은 역할을 미칠 가능성이 있다고 전제하고, 이를 여하히 활용하 느냐로 고심해야 할 것이다.

그런데 중요한 또 하나의 측면은 중국의 성장률이 과거 20 여년간, 그리고 앞으로 상당기간 연 평균 $7 \sim 9 \%$ 를 기록했거나 기록할 것으로 전망된다는 측면이다. 즉 역내에서도 중국의 중요성이 급격히 증가될 것으로 전망되고 있다. 이러한 사실은 단순히 중국의 중요성이 증대되는 측면 이외에도 대외경제의존도가 높은 우리나라는 향후 중국의 고속 경제발전에 연동관계를 적어도 하나는 걸어두어야 할 필요성이 있다는 것을 간접적으로 설명해 주고 있다. 그 만큼 우리나라도 역내경제에 더 관심을 두고 신경을 써야 할 필요 가 있음을 인식할 필요가 있는 것이다.

중국의 고속성장과 관련해서 두 번째로 중요한 것이 국내 부동자금의 보다 원활한 활용이다. 역내에서 일본, 한국이 이미 실질이자율이 마이너스로 변한 만큼, 이를 여하히 역내에서라도 보다 효율적인 방향으 로 사용할 수 있도록 바꿀 수 있느냐가 무척 중요하다. 일본이 마이너스 이자율로 된지가 이미 오래고, 한 국이나 중국도 이자율이 무척 싼 형편이다. 중국은 개발자금의 동원을 위해서 저이자율의 유지가 나름대 로의 논리가 있다. 하지만 한국의 경우 투자처도 없어진데다가 신규수요를 발굴할 여지도 쉽지않게 된 그 러한 형편에서 저이자율이 지속됨으로써 오히려 문제가 생기게 된 것이다. 따라서 우리로 보아서는 상당 한 부동자금을 역내에서, 가령 China Fund화해서 중국으로 투자할 필요가 있다.

(4) 역내 산업구조조정의 최적화

또 하나가 우리나라 산업구조 조정의 새로운 모색과 연관된 것이다. 당장 우리나라의 구 산업지도를 정리해야 할 필요가 있다. 우리나라는 전통적으로 산업발전의 경로가 1) 외국으로부터의 기술수입 $\rightarrow 2$ ) 설비수입에 의한 신규투자 단계 $\rightarrow$ 3) 신규제품 생산 후 해외수출 $\rightarrow$ 4) 외환가득 $\rightarrow 5$ ) 재투자의 행태를 반 복하고 있는 중이다. 그러나 이러한 투자, 산업구조는 세계화 및 중국경제의 급격한 부상을 특징으로 하는 새로운 체제하에서는 먹혀들기가 쉽지 않다고 볼 수 있다. 따라서 이 측면에서도 새로운 산업역량, 동력의 집중을 위한 신성장축을 발굴해야할 필요가 있는 것이다.

a NAFTA의 출범초기인 1995 년에는 미국의 대 NAFTA의존도가 수출 $29.4 \%$ 였으나 2001 년에는 $36.3 \%$ 로 늘어 났으며 수입은 $26.8 \%$ 에서 $30.5 \%$ 로 늘어났다. 


\section{2. 입지론적인 관점에서의 한국의 비교우위 평가}

\section{(1) 입지론과 중국 경제발달지역의 고찰}

우리나라의 비교우위를 검토하기 위해서는 가장먼저 중국의 경제권역을 고찰해볼 필요가 있다. 왜냐 하면 우리의 주장대로 "동북아경제중심"이 되려면 가장먼저 중국의 전체적인 맥락에서 우리가 갖는 입지 적인 잇점이 어디에 있는지가 검토되어야 하기 때문이다. 우선 전통경제학에서는 입지론(location theory)에 대한 고려는 그리 많지 않다. 최근 한 세대 이상 주류경제학은 거시경제학과 미시경제학, 국제 경제학 등을 중심으로 시장의 관점과 정부의 역할, 금융의 역할등을 주로 다루고 있다. 그런데 입지이론은 미시적차원에서 구체적인 경제활동을 영위하는 과정에서는 보다 중요한 지위를 차지하게 된다. 19세기 초 엽의 독일 경제학자이던 폰 튜넨은 도시의 탄생을 입지론적인 관점에서 설명 하하고자 하였다. 즉 토지의 생산력이 제일좋은 지역을 중심으로 도시가 형성된다고 주장하며, 지대와 거래비용의 상충관계가 도시형 성의 핵심이라고 주창한다. 즉 한 지역으로부터 동심원을 그려서 거래비용과 지대가 균일화 되는점을 찾 았을 때 동심원의 중심이 바로 도시가 되는 것이다.

동북아경제중심과 관련해서 주목되는 입지이론은 네덜란드의 니캄프 ${ }^{2 \prime}$ 로 그는 입지결정의 가장 중요 한 결정요소로 교통, 통신, 에너지, 용수, 환경, 교육, 의료, 도시, 체육과 여행, 사회기반, 문화, 그리고 자연 부존 등 사회간접자본의 영역을 중심으로 12 개를 들고 있다. 니캄프의 이론을 동북아경제중심에 적용하게 된다면 중국, 한국, 일본에서 과연 위와같은 12 개 영역에서 우위를 가지고 있는 지역이 어디인가를 검토해 야될 필요가 있다는 것으로 집약된다.

동북아경제중심을 평가하기 위해서 이상의 입지론을 바탕으로 해서 우리나라의 가장 핵심적인 경쟁상 대인 중국의 경제권역을 일별해 보기로 한다. 즉 중국의 경제발전 핵심지역을 니캄프의 이론에다가 인구 밀집, 넓이, 소득, 교역, 외국인투자, 대학교육등을 추가해서 분석해 본다면 대체로 4 개 지역이 동북아경제 중심의 후보지를 추출할 수 있다. 즉 필자는 중국이 대체로 전국 31 개 성급 행정구역을 기본단위로 해서 4 개 경제발전 지역으로 나눌 수 있다고 본다. 가장 중요한 것이 샹하이 일대 ${ }^{21}$ 의 35 만 $k n^{2}$ 로서 남 - 북한을 합 친 넓이보다 크며, 인구 또한 2 억명에 육박한다. 경제규모 또한 RMB 2조 5천억(약 3,000 억 달러상당)으로 전국의 $25.5 \%$ 를 차지하고 있으며 교역 $27.2 \%$, 외국인 투자유치 누계액 $28.3 \%$, 고정자산투자 $28.8 \%$, 고등 교육기간 분포 $17.1 \%$, 고급학생재학 비중 $19.6 \%$ 이상등 중국전체로 보아서 월등한 지위를 차지하고 있다.

둘째로 중요한 지역이 홍콩이 포함된 광둥성 지역이다. 면적 19 만k피에, 인구 8,450 만명, 소득 RMB 2 조 5 천억 수준으로 전체 중국 가운데 경제규모 $25.7 \%$, 외국인 투자 $74.8 \%$, 총투자 $10.5 \%$ 등의 위상을 차지 하고 있다. 여기서 우리가 주의해야할 것은 경제규모와 외국인 투자등에서 홍콩이 광둥성에 포함되어있다 는 것이다. 이는 이론의 여지가 있으나 홍콩과 인근 광둥성의 션쩐이 현재 경제적으로 통합이 거의 이루어 졌다고 해도 과언이 아닐 정도가 되었다. 이러한 결과와 함께 $\mathrm{CEPA}^{2 n}$ 가 발표된 바 있다.

다음으로 중요한 것이 수도권지역 ${ }^{\infty}$ 으로 21.81 만 $k^{2}$ 의 넓이에 9,086 만명의 인구가 있다. 경제규모 또한 전국의 $10 \%$, 교역 $14.8 \%$, 외국인 투자 $10.5 \%$, 총 투자 $14.2 \%$, 고등교육기관 집중도 $12.8 \%$, 고급인력 배출 비중 $11.7 \%$ 등으로 또 하나의 핵을 이루고 있다. 마지막으로 주목되는 것이 충칭과 쓰촨성이다. 이곳은 인 구1억 1,737 만명으로 그 넓이가 무려 57 만쬬가 된다.

20) 마크 블라우(1999)

2n 니캄프(1984)

281 상하이를 중심으로 져장, 안훼이, 쟝쑤지역을 포괄한다.

${ }^{21}$ Closer Economic Partnership Arrangement를 나타내는 것으로서 홍콩의 경제적 침체를 방지 한다는 차원에 서 중국대륙이 홍콩에 대해서 경제 헙력을 보다 강화하기 위한 다각적인 우대조치를 주 내용으로 하고 있다.

베이징, 허베이. 텐진등이 포함된다 
경제규모는 전국의 $6.4 \%$ 인데 이는 아직 교역 $(10 \%)$, 외국인투자 유치 $(2 \%)$ 등에서 나타나 있는 것 처럼 대외교류가 부진한 결과로 평가할 수 있다. 그러나 발전 잠재력은 굉장하다고 할 수 있다.

우선 중국정부의 서부대개발 계획의 핵심지역이 일단 이 지역에 집중되고 있다는 점이다. 또한 전통적 으로 이 지역은 미얀마, 베트남등과 인접해 있음으로 인해 이들과의 교류가 확대될 수 있는 잠재력도 있다. 따라서 우리나라가 동북아 경제중심이 되기 위해서는 당장 이상 지역에 비해 중국에 비해 뭔가 우위를 지 녀야 한다는 한계를 극복해야 한다. 여기에다가 일본의 도쿄, 오사카 지역까지를 포괄하게 된다면 논리는 횔씬 복잡해지게 될 것이다.

\section{(2) 우리의 비교우위 평가}

일단, 우리나라는 지리적으로 중국과 일본사이에 위치하고 있다는 지리적인 잇점이 있는 것이 사실이 다. 이를 근거로 해서 많은 식자들이 우리가 거중조정이 가능하다는 논리를 주로많이 펴는 것 같다. 물론 이는 꼭 잇점은 아닐수도 있다. 왜냐하면 중국이 앞에서 본대로 하나의 국가라기 보다는 적어도 4 개의 권 역이 경쟁하는 연합국가로 인식된다는 것이다. 그만큼 중국과의 비교에서 우리의 지역적인 잇점이 현재화 할 수 있느냐는 또 다른 애기가 된다. 그러나 다행히도 우리나라의 평균적인 발전의 수준이 그래도 중국에 비해 아직은 앞서있고, 자본주의 시장경제도 좀더 오래 경험했다는 점 등에서 우리가 하기에 따라서는 우 리의 역할을나름대로 자리매김할 수 있을 여지가 있다.

물론 앞에서 살펴본 것처럼 중국의 발전이 4 개의 핵에 의해서 이루어진다는 점에서 쉽지 않으리라는 것이다. 그러나 중국은 영토가 광할하여 하나의 경제권역으로 보기는 어렵다. 특히 화북지역과, 한반도, 일본을 포함할 경우 아시아 전체발전의 관점에서 “동북아경제권"이라는 하나의 경제권으로 발전시킬 수 있을 것 이다. 우리가 주창하는 “동북아경제협력중심"의 개념도 이러한 관점에서 유효하게 될 것이다. 중 국으로서는 화남과 동남아를 묶는 경제권역과, 화중자체의 경제권, 그리고 동북아경제권이 있게되며, 이들 이 서로 경쟁하면서 협력하여 발전하게 되는 경우, 궁극적으로는 중국전체 발전에 커다란 역할을 할 수 있 게된다. 우리도 인근에 발전을 하고 있는 국가가 있으면 유리하며, 중국 또한 인근에 우리와 같은 경제발 전지역이 있는 것이 대승적으로는 유리하게 될 것이다. 이러한 관점에서 우리나라의 잇점이 있게된다.

또한 역내에서 우리의 강점은 상대적인 소국이라는데 있다. 즉 그 만큼 입장을 정확히 세운다고 가정 하고 국민적인 합의가 이루어 진다면 변화할 수 있는 합의를 쉽게 이룰 수 있는 것이다. 이것은 얼마나 훌 륭한 지도자가 식견을 가지고 만들 수 있느냐에 달려 있다고 할 수 있다. 광범위한 중국이나. 나름대로의 선진화를 달성한 아주 보수적인 일본에서는 찾아 볼 수 없는 역동성 (mobility)을, 하기에 따라서는 우리만 이 발휘 할 수 있다.

또 하나는 발전의 후발주자로서 최근 35 40년만에 1 인당 소득 83 달러의 극빈 후진국으로부터 개인소 득 1 만달러의 선진국 문턱에 진입한 경험이 있다는 것이다. 사람은 경험을 하지 못하면 영원히 인식하지 못하고 후퇴하게 될 가능성이 크다. 그러나 우리는 1 세대 남짓한 그 짦은기간에 다른 선진국들이 100 년 이 상에 걸쳐 이룩한 업적을 달성한 것이다. 따라서 세계의 많은 사람들이 현재의 현존 세대로서 한국의 경험 을 통해서 향후 궤적을 추적해 볼 수 있는 장점이 있다. 특히 중국의 경우는 한국이 때로는 모방해야할 대 상으로서, 때로는 실패를 극소화(최소화)하는 대상으로서 각각 중요성을 갖게 될 것으로 보인다.

마지막으로, 우리나라에는 북한의 1,700 만 인구에다가 600 만에 달하는 전세계 각지에 분포해 있는 교 포'들이 있다.

\footnotetext{
311 이들을 묶기 위해서 세계 한상대회가 개최되고 있다.
} 
우리민족은 중국, 러시아, 일본, 미국 등 세계열강에 많은 교포들이 진출해서, 성공해 있는 사람들도 적 지 않는 것으로 평갈된다. 이들과의 연계관계를 잘 활용하기에 따라서는 나름대로의 큰 자산으로 활약할 수 있을 것이다.

\section{IV. 향후 역내 경제협력긴밀화 구상}

이상 우리는 역내 협력구상에 대한 전반적인 문제를 검토 하였다. 그러면 우리는 역내, 역외에서 여하 한 입장을 취 할 수 있젰는가? 일부에서는 미국까지 포함된 APEC의 구도로 들어가야 한다는 주장, 또한 일부에서는 ASEAN+3국(중국, 일본, 한국)간 협력의 강화 구상, 그리고 또 한편에서는 동북아 3 국간 공동 체 형성구상, 독자노선 구상 등을 다양하게 제기하고 있는 실정이다. 필자가 보기에는 그 주장에 나름대로 의 일장일단이 있다고 판단한다. 문제는 우리의 인식(Paradigm)을 여하히 바꿀 수 있느냐에 달려있다고 본다.

필자가 보기에는 큰 역사의 흐름에서 보아 30 50년 뒤에 시장의 힘에의한 자연발생적인 "동북아경제 공동체”로 까지 진전된다는 것은 필연인 것 처럽 보인다. 그러나 우리가 또 다시 명시적으로 "동북아경제 중심”을 “동북아공동체구상”의 변형으로 주창하고 나선다는 것은 소탐대실할 소지가 크다. 즉 역외시장이 큰 만큼 아직은 배타적인 구상으로 비쳐질 “동북아경제중심"론은 최소화 하면서 기존에 논의되는 덜 민감 한 사항에 집중해야할 것으로 판단한다. 즉 앞에서도 제기했던바 처럼 우리나라는 단기적으로는 모든경제 협력에 다층적으로 관여하면서 궁극적으로는(장기적으로)시장의 힘에 의해서 동북아경제공동체가 자연스 럽게 성사될 수 밖에 없다는 긴 안목을 가질 필요가 있다. 이러한 측면에서 필자의 잠정적인 결론은 단기 적으로 FTA를 포함한 여러 공동체에 다층적으로 참여 하면서, 장기적으로 우리 내부의 힘을 키우는 "자 강"의 노력에 더 큰 힘을 쏟아야 할 때로 판단된다.

현재 우리나라는 경제규모에 있어 세계 250 여개 국가 가운데서는 그래도 13 위로서 엄청난 규모로 커온 것이 사실이다. 즉 한 방향이 선정 된다면 성장할 여지가 충분히 있는 것이다. 그러나 중 - 장기적으로는 역시 한국의 새로운 식견은 고루한 단일민족개념이나 쇼비니즘적인 인식에서 크게 탈피해서 세계국가로 거듭나야 한다. 이러한 노력은 우리 역사상 거의 초유의 시도일지 모른다. 일견 어려운 과제로 보이기는 하지만 앞에서 애기한 장점만 극대화 할 수 있다면 충분히 가능하며, 이 과제는 결국 교육의 개혁 (Contents위주)에서 물꼬를 틀 수 있을 것이다. 일부에서는 경제문제를 해결하는데 교육이 왜 필요하느냐 는 주장을 펴기도 하겠지만 Paradigm의 Shif가 일어나기 위해서는 교육의 개혁밖에 없다. 이러한 측면 에서 1980년대 "경제교육"이 한 때 강조된 것은 주목할만 하다. 다시 말해서 아시아적 발전의 단초는 서구 문명의 조기수입, 신사유람단의 파견, 국내교육 제도의 개혁을 통한 신규 Paradigm의 형성, 그리고 개발 전략의 추구로 이어진다고 볼 수 있다. 이러한 맥락에서도 최근에 재음미 되고 있는 유길준의 “중립론”등 도 과거 우리의 선조들이 얼마나 주어진 여건하에서 활로를 개척하기 위해서 어렵게 고민했는가를 반영해 준다는 차원에서 상당한 의미가 있다. 이는 일부에서 제기되고 있는 “소강국"개념이나 필자의 "알짜국가 론" ${ }^{33}$ 등과도 연관지을 수 있다는 측면에서 그 의미가 있다.

30 외교통상부 집계에 따르면 재외동포의 현황은 다음과 같다. 미국 216만, 중국 214만, 일본 64 만, 구쏘련지역 56 만, 캐나다 17 만, 브라질 5 만명 등 총 607 만명으로 추계되고 있다.

39) 졸고(2003) 참조하기 바람. 
따라서 역내 통합의 장기적인 성사를 위해서 정치 $\rightarrow$ 경제 $\rightarrow$ 사회 $\rightarrow$ 문화의 순서가 아닌 문화 $\rightarrow$ 사회 $\rightarrow$ 경제 $\rightarrow$ 정치의 역순으로 준비하고 접근해야할 것이다. 아래에서는 장기적 “동북아경제공동체 구상”이 실현되기 위해서 여하한 형식으로, 어떠한 단계를 밟아서, 여하히 실현 할 수 있는지에 대해서 필자의 논지 를 좀더 상술하기로 한다.

\section{1. 형 식}

기존 역내 협력의 형식은 대체로 Bella Ballasa가 제기한 바처럼 상품교역의 원활화 $\rightarrow$ 투자 등 요소 이동의 원활화 $\rightarrow$ 인적교류의 활성화 $\rightarrow$ 금융협력단계 $\rightarrow$ 그리고 마지막으로 정치공동체의 형성 단계로 진 전되는 것을 보편적인 현상으로 판단하고 있다. EU가 이미 최종단계로 향하고 있으며 NAFTA가 그 전 단계로 까지 진전된 것으로 평가 할 수 있다.

하지만 동북아에서는 오랜냉전시대 단절의 회복에 따른 조정, WTO등 세계화의 진전, 그리고 지역주 의의 극복 등 몇 가지 복합적인 요인에 의해서 “선인적 요소 이동” $\rightarrow$ “후 시장 형성” $\rightarrow$ “금융협력” $\rightarrow$ “공 동체 출범” 등 새로운 형식을 취하지 않으면 않되게 되어 있는 것으로 판단된다. 즉 중국, 일본, 한국 등 3 국은 냉전시대를 거치면서 인위적으로 국경간 거래가 한때 장기간 단절됨으로써 이를 극복하기 위해서도 훨씬 더 획기적인 교류의 확대가 일어나고 있다고 판단된다. 중 · 일간, 한 · 중간 교역이 수교직후 폭등" 졸고(2003) 참조하기 바람한 것은 냉전시대 이전 경제교류의 "과거로의 회귀"요인 이외로는 도저히 설명하 기 어려운 현상인 것이다.또 하나 중요한 것이 WTO로 인한 세계화의 강력한 진전에 따라서 역내 협력의 강화 내지는 경제교류의 긴밀화가 새로운 형태를 뗠 수 밖에 없다고 볼 수 있다.

셋째, 지역주의의 만연이다. EU와 NAFTA가 이미 저만치 가 있는 만큼 우리도 아시아 내에서 궁극 적으로 역내 경제협력체를 형성해서 세계시장을 안정화 시켜야 할 필요가 있다고 한다면, 보다 구체적으로 진전 시켜야 할 필요가 있다고 본다. 이러한 몇 가지 요인으로 향후 역내 공동체 형성은 형식이나 실행방 안이 기존의 틀과는 다소 다르게 나와야 한다고 판단한다.

\section{2. 단계별 접근}

우선, 고려될 수 있는 것이 단계별 접근법이다. 즉 우리로서는 “동북아공동체구상”이 빨라야 약 20여 년은 소요될 것이라는 장기적인 관점 하 에서 1 5년 이내의 단기, 6 10년간의 중기, 그리고 10년 이상의 장 기기간을 설정, 이를 각각 여하히 실행해야 할 것인가에 대해서 심각하게 논의해 보아야 할 것으로 보인다. 여기서는 단순히 경제적인 측면만을 강조해 본다면 다음과 같이 단계별 접근방법을 정리해 볼 수 있을 것 이다.

첫째, 향후 5년 이내에는 한 · 중 · 일 3국간에 투자와 무역이 결합된 협력이 대대적으로 일어나게 될 것 이다. 우선 투자의 핵심에는 역시 중국대륙이다. 중국에는 2001년 말 WTO에 가입하고 난 후 제2의 "차이 나러쉬”현상이 일어나고 있다. 즉 세계적인 기업체들이 중국의 시장을 선점하기 위해서 너도나도 불문하 고 진출하고 있다. 그 결과 2002년 부터는 중국이 세계최대 FDI유치국가로 부상하게 되었다. 그 결과 역 내에서도 투자, 무역과 관련된 상당한 변화가 나타나고 있다.

현재 역내에서는 한국은 물론이고 일본의 많은 업체들이 중국으로의 투자에 나서고 있는 것으로 집계 되고 있다. 특히 홍미로운 것은 일본 업계의 변화 움직임이다.

30 가령 한 - 중 수교 첫해인 1992 년의 경우 교역이 그 전해에 비해 무려 $43.5 \%$ 이상 늘어나게 되었다. 
일본 업계는 중국과의 경쟁심리에 의해서 기술유출을 우려하여 중국투자에 인색했다는 평가를 받아 온바 있었다. 그러나 최근에 들어와서는 많은 일본업체들이 중국에 진출하는 것이 불가피하다는 평가를 바탕으로 부품업체들과 공동으로 진출하고 있는 실정이다. 이 현상은 우리나라 업체에서도 마찬가지로 나 타나고 있다. ${ }^{35}$

이렇게 된다면 한 - 중 - 일 3국간에는 자연적으로 역내 산업구조 조정이 가속적으로 일어나게 된다고 볼 수 있다. 즉 구태여 정부간의 협상이나 정치 지도자간의 커다란 노력이 없더라도 시장의 힘에 의해서 자연 발생적으로 역내협력이 보다 구체화 될 수밖에 없을 것으로 판단된다. 즉 단기간에서는 정부의 역할 이란 것이 최소화 될 수 밖에 없을 것이다.

둘째, 보다 긴 (6 10년)중기 산업협력이다. 이는 역시 정부가 나서서 EU의 Airbus프로젝트와 유사한 형태의 동북아 또는 동아시아적 상징적인 제품의 연구 및 개발등이 있어야 한다고 본다. 현재 각 국의 정 부가 나서서 개별기업들로 하여금 산업구조조정을 강제한다면 이는 거의 불가능할지 모른다. 오히려 새로 운 미래 산업으로서 세계에 존재하지 않은 제품으로서 세계평화나 복지향상에 도움이 되게 될 상징적인" 동아시아적 제품"을 추출, 이를 공동연구하고 개발하는 단계가 필요하다고 본다. 이 단계에는 SOC의 공 동이용, 에너지 활용방안, 아시아적인재육성등도 광범위하게 논의, 추진될 수 있을 것이다.

셋째, 첫단계나 둘째단계를 바탕으로 해서 장기적으로 요소의 자유로운 이동까지도 포함된 본격적인 산업협력의 단계로 이동할 수 있을 것이다. 세계 제 2 차대전 이전의 한 - 중 - 일 관계나. 중국중심의 동아시 아 질서시대 등이 어쩌면 장기적으로 불가피하게 다가오게 될 수도 있다는 것이 우리에게 중요한 교훈을 제공할 수 있을 것이다.

\section{3. 구체적 실행방안}

\section{(1) 동북아연합이공 대학촌 건설}

첫째, 동아시아적 상품의 새로운 공동제작이다. 이는 보다 구체적으로 가칭 “동북아연합이공대학촌" 을 설치해서 그 실행 단계에서는 한국, 중국, 일본에 각각 분교를 설치해서 이 대학촌에서는 3 국의 학생, 교 수, 업체등이 자유롭게 드나들 수 있도록 하여 동아시아 고유상품의 연구개발이 가능토록 해야 한다. 이는 기존의 제품을 통한 업체 및 국가간 협력보다는 신규 제품을 통한 업체간 및 국가간 협력이 훨씬 더 용이할 것으로 판단되기 때문이다. 즉 중국의 상하이 푸둥지역, 한국의 영종도지역, 일본의 칸사이지역등에 가령 “동북아연합이공대학촌-푸둥”, “동북아연합이공대학촌-영종도”, “동북아연합이공대학촌-칸사이”등지를 설립하고, 한 - 중 · 일 학생을 공동으로 뽑고, 공용어로 영어를 쓰되, 한 - 중 · 일어로도 강의하며, 각 대학 촌내에는 벤처형 중소기업체들이 입주하게 하여서 산 - 학 - 연을 구체화 토록 한다. 이를 통해서 궁극적으 로 동아시아적 상품을 공동으로 제작할 수 있게 될 것이기 때문이다. 이는 과거 아시아가 협력보다는 경쟁 관계속에서 서로 주도권을 주장하였던데서 탈피해서 새로운 인력의 배출과 교류를 통해서 경제교류를 자 연히 증가시키는 방안을 염두에 두고 생각하는 내용이다.

(2) 아시아지역전문가 양성

둘째, 국내에 있는 이공계 박사를 중심으로 중국이나 일본과 연관이 없다고 하더라도 적어도 연간 100 명씩5년간 5 백명에 대해서 2 년간씩 중국이나 일본현지에 파견, 근무토록 하여 업계를 지원해 주는 아시아 지역 전문가 양성 프로그램을 시행할 필요가 있다고 본다.

\footnotetext{
35) 조선일보 보도참조(2003. 11. 1 조중식기자 보도)

*) 구체내용 (사)한중경제포럼 보고서(2002) 참조
} 
이 프로그램을 시행하고자 주창하는 배경에는 적어도 한 · 중 및, 한 · 일 관계에서 인력의 불균형이 일 어나고 있다고 판단하기 때문이다. 즉 기술, 산업, 등 전문가 레벨에서 한 - 중간의 대화채널을 정확히 구 축할 필요가 있기 때문이다.

(3) 동아시아 규격의 제정

셋째, 신규제품에 대해서는 동아시아적 규격(specification)을 적용하여 이를 보다 세계화 시키는 노 력을 할 필요가 있다. 앞에서 제안한 “동북아 연합이공대학촌”의 개념에 따라서 동아시아적 규격의 제정 을 검토하자는 것이다. 즉, 가령 가능한 영역은 상징적으로는 역시 동양의학 분야로서 생명공학관련 공동 연구를 통한 공동 규격화를 통해서 아시아 내에서의 산업유발 효과 뿐 아니라 세계적인 산업유발 효과까지 도 겨냥 할 수 있을 것이다.

(4) 협회간 교류강화

넷째, 협회 차원의 한 - 중 - 일 3국 협의체의 구체화이다. 이는 단기 및 중기간의 업체별, 협회별 대화 를 상시화 함으로써 서로 자구노력을 할 수 있도록 제도화 해 주는 것이다. 물론 협회의 능력에는 일부 문 제가 있는 것으로 지적되고 있다. 따라서 우선 검토할 수 있는 것이 철강협회, 자동차협회, 석유화학협회 등 산업의 전 - 후방 효과가 큰 중화학분야로서 3 국의 협력이 각국의 산업자체 발전은 물론이고 역내 산업 발전에 영향을 크게 미치게 될 분야를 도출하고 이를 공동으로 발전시켜 나가는 것을 모색하는 것이다.

\section{(5) 은퇴기술자 활용}

마지막으로 역내구조조정에 추진에 따라서 이루어 지게될 산업설비의 매각시 중소기업을 중심으로한 교류의 권장 및 은퇴 기술자의 활용이다. 한국과 일본은 이미 고령화 시대로 이전 되어서 심지어 " 45 정, 56 도”라는 우스개" 소리가 나오고 있는 실정이다. 따라서 아직까지 육체적으로나 경험적으로 유효한 인적 자원인 은퇴기술자를 서로 파견하여 조금이라도 더 경제발전에 활용하는 것이 필요하다고 본다. 이미 중 국에는 30만명의 우리나라 국민이, 그리고 우리나라에는 20 만명 정도의 조선족이 상주하고 있는 것으로 집 계되고 있다. 그 만큼 인적 교류까지 포괄된 협력이 늘어나고 있다는 것을 반증해 주고 있다. 이들 인적교 류가 단순한 3D업종에서 그치는 한계 및 교류를 뛰어 넘어서 선진기술 영역으로 확대된다면 그 만큼 역내 산업협력이 더더욱 진전될 것으로 평가되고 있다. 역시 경제공동체 구상의 궁극적인 목적은 개별 국가내 의 요소 최적배분의 국가목표를 뛰어 넘어서 역내 요소 최적 배분 및 활용을 겨낭한다는 측면에 있다는 점 을 감안, 보다 현실성 있는 방안이 될 것이다.

\section{참고문헌}

Blaug, Mark (1997) Economic Theory in Retrospect. Cambridge: Cambridge University Press, 1997.

Cheong, Young-Rok(1999) Comparison of FDI into China Vol.28 No.1, GER, Yonsei University Deng, Xiaoping(1983), Selected Works of Deng Xiaoping.

Hoover, Edgar M. (1948) The Location of Economic Activity. New York; Toronto; London: McGraw-Hill Book Company, Inc. p.277.

\footnotetext{
3) 45 세가 실질 정년이며 56 세까지. 직업을 갖고 있다면 도둑이라는 뜻이다.
} 
Kennedy, Paul(1989) The Rise and Fall of the Great Powers: Economic Change and Military Conflict from 1500 to 2000, Vintage Books Kerr, D. (1965). "Some Aspects of the Geography of Finance in Canada". Canadian Geographer, 9, 4, 175-92.

KITA(2002) Korea and the World-Key Indicators

Marshall, Alfred (1920) Principles of Economics. London: Macmillan (8th ed.)

Nijkamp, Peter (1984) “A Multidimensional Analysis of Regional Infrastructure and

Economic Development.” In ke E. Andersson, Walter Isard, Tnu Puu, eds., Regional and Industrial Development Theories, Models, and Empirical Evidence. Amsterdam: North-Holland.

Perkins, Dwight H.(1988) “Reforming China' s Economic System,” The Journal of Economic Literature, Vol. 26, No. 2(June), American Economic Association.

Porteous, David (1998) "The Development of Financial Centers: Location,

Information Externalities and Path Dependence." In Ron Martin, eds., Money and The Space Economy. Chichester: John Wiley \& Sons. pp.105-113

WEFA(2001) World Economic Outlook, Second Quarter 2001

World Bank(1997) China 2020: Development Challenges in the New Century, New York.

國家統計局(1982-2001),『中國統計年鍳』, 각년판. 北京: 國家統計出版社.

(2002), 『中國統計摘要』, 北京: 國家統計局.

國務院發展研究中心(1999), 『未來20年我國經濟發展前景分析』, 北京: 中國發展出版社.

謝平(2000), “中國銀行業的改革与對外開放,”王夢奎主編,『中國2010』, 北京: 中國發展出版社

王夢奎 主編(1999)、『中國經濟轉軌二十年』, 北京: 外文出版社.

外經貿部 (2000), 『中國對外經浧貿易白皮書 2000』, 北京: 中國社會科學出版社. (2002), 『中國對外經濟貿易白皮書 2002』, 北京: 中國物資出版社.

劉國光(2000), “21世紀初中國經濟發展与經濟結構調節問題, KIEP 중국경제연구회 발표자료.

李京文(2001), “21世紀中國經濟發展䞶勢,”中國宏觀經濟信息網.

李善同·翟凡 ·侯永志(2000), “中國經濟增長的前景, ”王夢奎 主編, 『中國 2020: 目標, 政策与前景』,

北京: 中國發展出版社, pp.18-31.

李成勋 主編(1999), 『2020年的中國』, 北京: 中國發展出版社.

日本經濟研究センター $(2000), 『 2020$ 年の中國』, 3月.

張卓元(1999), “國有企業改革-二十一世紀初中國經濟改革的主題,”企業改革之聲』第4期.

(사)한중경제포럼(2002) 중국전문가 양성 및 재중 동포교육강화 및 방안 정책연구 (2002. 10), 교육인적자원부 손병해(2002), 경제통합의 이해, 법문사

정영록(1992), 동북아지역 무역구조와 역내 수출경쟁력 비교(1992.1), 대외경제정책연구원(KIEP) 정책연구 정영록(1996), 대중 통상정책의 한 · 일 비교 분석(1996.12), KIEP 정책토의자료

정영록(1997.11), 동북아시대에 대비한 한국의 경제적 진로, 「한국북방학회논집」

정영록(1998), 중국 원화환율 전망과 정책과제, (봄호, 대외경제정책연구), 대외경제정책연구원

정영록(2002), 중국의 이동통신시장 진단과 전망, Telecommunication Review, Special Issue 2002,

July 2002

정영록(2003a), 중국경제의 부상: 우리에 대한 의미평가, 경제학연구, 창립50주년기념호, 2003, pp235-260

정영록 · 이종건(2003b), 중국경제의 부상과 우리나라의 산업정책방향, 금융경제연구 2003. 7 제 161 호,

한국은행 금융경제연구원 